\title{
Synthesis and Characterization of Complexes of Some Transition Metals with Two Bifunctional Thiourea Derivatives
}

\author{
ZOHRA SOLTANI ${ }^{1}$, AHMED THENIA $^{1}$, MOHAMMED BOUCHEKARA $^{1}$, INAS EL \\ HASSAN $^{2}$, HANNA EL-NAKAT ${ }^{3}$, FAWAZ EL OMAR ${ }^{2}$ and AHMAD ALLOUCH ${ }^{2}$
}

\author{
${ }^{1}$ Laboratory of Process Engineering and Solutions Chemistry, Faculty of Sciences and \\ Technologies, University Mustapha Stambouli of Mascara, Algeria \\ ${ }^{2}$ Laboratory of Applied Chemistry (LAC), Faculty of Sciences III, Lebanese University, \\ P.O. Box 826, Tripoli, Lebanon \\ ${ }^{3}$ Department of Chemistry, Faculty of Sciences, University of Balamand, P.O. Box 100, \\ Tripoli, Lebanon \\ aallouch@ul.edu.lb
}

Received 2 November 2017 / Accepted 23 November 2017

\begin{abstract}
Synthesis and characterization of complexes of $\mathrm{Fe}(\mathrm{II}), \mathrm{Ni}(\mathrm{II}), \mathrm{Zn}(\mathrm{II}), \mathrm{Hg}(\mathrm{II})$ and $\mathrm{Cu}$ (II) with two thiourea derivatives such as $N$-(2-methylphenyl), $N^{\prime}$-(2,3-dimethylphenyl)thiourea $\left(\mathrm{H}_{2} \mathrm{~L}_{1}\right)$ and $N$-(2-methylphenyl), $N^{\prime}$-(2-chlorophenyl) thiourea $\left(\mathrm{H}_{2} \mathrm{~L}_{2}\right)$ have been studied. Their structures were confirmed by IR spectroscopy. The ligands $\mathrm{H}_{2} \mathrm{~L}_{1}$ and $\mathrm{H}_{2} \mathrm{~L}_{2}$ used were prepared according to the procedure reported in the literature
\end{abstract}

Keywords: Synthesis, Thiourea complexes, Transition metals

\section{Introduction}

$\mathrm{Fe}, \mathrm{Ni}, \mathrm{Zn}, \mathrm{Hg}$ and $\mathrm{Cu}$ are essential elements for biological systems when present in minor quantities. On the other hand, these metal ions play an important role in mineral chemistry and their heavy use in industrial production is one of the major causes of environmental pollution. In both cases, it is absolutely essential to understand the role of these metal ions in biological systems by carrying out the structural studies of biological compounds and to examine their metal complexes.

Bifunctional chiral thioureas, derivatives of $N$-(2-methylphenyl)- $N$ '-(2-methylphenyl) thiourea are active traps of the heavy metals. In fact, they are employed as inhibitors for metals corrosion in aqueous aggressive environments ${ }^{1}$. They play also an important role in the field of asymmetric organocatalysis ${ }^{2}$, such as the cyanosilylation of ketones ${ }^{3}$, Michael 
additions $^{4}$, Baylis-Hillman reactions ${ }^{5}$ and hydrophosphonylation of imines ${ }^{6}$. In addition, they show a broad spectrum of biological activities such as antibacterial, antiviral, anticancer and anticonvulsion $^{7-9}$. Their success is based upon their rigid, semi planar structures which provide sites for a number of important substitutions. As well, the presence of one or several heteroatoms permits interactions, of electrostatic type (hydrogen-bond, Vander Waalsbond.... $)^{10}$.

The donor hetero atoms $(\mathrm{O}, \mathrm{N}$ and $\mathrm{S})$ of the thiourea derivatives have several modes of coordination. The ligands and their metal complexes display a wide range of biological activities, including antibacterial, antifungal, anti-tuberculosis, antithyroid, anthelmintic, rodenticides, insecticides, herbicides, and plant growth regulating properties ${ }^{11}$.

In the present study, we report the synthesis and characterization of complexes of $\mathrm{Fe}(\mathrm{II})$, $\mathrm{Ni}(\mathrm{II}), \mathrm{Zn}(\mathrm{II}), \mathrm{Hg}(\mathrm{II})$ and $\mathrm{Cu}(\mathrm{II})$ with two thiourea derivatives: $N$-(2-methylphenyl), $N^{\prime}$-(2,3-dimethylphenyl)thiourea $\left(\mathrm{H}_{2} \mathrm{~L}_{1}\right)$ and $N$-(2-methylphenyl), $\quad N^{\prime}$-(2-chlorophenyl) thiourea $\left(\mathrm{H}_{2} \mathrm{~L}_{2}\right)$. Their structures were confirmed by IR spectroscopy. The ligands $\mathrm{H}_{2} \mathrm{~L}_{1}$ and $\mathrm{H}_{2} \mathrm{~L}_{2}$ used were prepared according to the procedure reported in the literature ${ }^{12}$ as shown in Scheme 1.<smiles>[R]c1cccc(NN)c1[R]</smiles><smiles>[R2]c1cccc(NC(=S)Nc2ccccc2C)c1[R]</smiles>

$$
\begin{aligned}
& \mathrm{H}_{2} \mathrm{~L}_{1}: \mathrm{R}_{1}=\mathrm{CH}_{3}, \mathrm{R}_{2}=\mathrm{CH}_{3} \\
& \mathrm{H}_{2} \mathrm{~L}_{2}: \mathrm{R}_{1}=\mathrm{Cl}, \mathrm{R}_{2}=\mathrm{H}
\end{aligned}
$$

Scheme 1. Synthesis of $N$-(2-methylphenyl), $N^{\prime}$-(2,3-dimethylphenyl) thiourea $\left(\mathrm{H}_{2} \mathrm{~L}_{1}\right)$ and $N$-(2-methylphenyl), $N^{\prime}$-(2-chlorophenyl) thiourea $\left(\mathrm{H}_{2} \mathrm{~L}_{2}\right)$ ligands

The synthesis of the complexes between ligands $\left(\mathrm{H}_{2} \mathrm{~L}_{1}\right.$ and $\left.\mathrm{H}_{2} \mathrm{~L}_{2}\right)$ and metals is performed ${ }^{13-16}$ according to the Scheme 2 . The synthesis is based on a reaction between an acid (electrons acceptor) $\mathrm{M}$ (II) / and a base (electrons donor) Ligand.

$$
\begin{array}{lll}
\mathrm{MCl}_{2} \cdot \mathrm{xH}_{2} \mathrm{O}+\mathrm{nL} \longrightarrow \mathrm{M}(\mathrm{L})_{\mathrm{n}} \cdot 2 \mathrm{Cl} & (\mathrm{n}=2,3,4) \\
\mathrm{M}=\mathrm{Fe} ; \mathrm{x}=4 ; & \mathrm{T}=0^{\circ} \mathrm{C} \\
\mathrm{M}=\mathrm{Ni} ; \mathrm{x}=0 ; & \text { reflux for } 1 \text { hour } \\
\mathrm{M}=\mathrm{Zn} ; \mathrm{x}=0 ; & \text { room Temp. } \\
\mathrm{M}=\mathrm{Hg} ; \mathrm{x}=0 ; & \text { room Temp. } \\
\mathrm{M}=\mathrm{Cu} ; \mathrm{x}=2 ; & \text { room Temp. }
\end{array}
$$

Scheme 2. Preparation of the complexes

\section{Experimental}

All chemicals were purchased from Sigma-Aldrich Chemical Company. Solvents were of the highest grade of purity commercially available and were used without further purification. The ligands $\mathrm{H}_{2} \mathrm{~L}_{1}$ and $\mathrm{H}_{2} \mathrm{~L}_{2}$ used were prepared according to the procedure reported in the literature ${ }^{12}$ as shown in Scheme 1. Their purities were verified by chromatography with silica gel using benzene as a mobile phase and their structures were 
confirmed by IR and ${ }^{1} \mathrm{H}$ NMR spectroscopy. All the complexes synthesized were identified by their FT-IR spectra, recorded on a FT-IR-4200 type A spectroscopy between $4000-400 \mathrm{~cm}^{-1}$. Water was purified by triple distillation.

\section{Preparation of metal complexes of $N$-(2-methylphenyl), $N^{\prime}$-(2,3-dimethylphenyl) thiourea $\left(\mathbf{H}_{2} \mathbf{L}_{1}\right)$}

Synthesis of complex of $\mathrm{H}_{2} \mathrm{~L}_{1} / \mathrm{Fe}$ (II)

The complex was prepared by the procedure described in the literature ${ }^{13}$. To a solution of $\mathrm{FeCl}_{2} \cdot 4 \mathrm{H}_{2} \mathrm{O}$ (199 mg in $20 \mathrm{~mL}$ of ethanol, $\left.1 \mathrm{mmol}\right)$, a solution of $\mathrm{H}_{2} \mathrm{~L}_{1}(540 \mathrm{mg}$ in $20 \mathrm{~mL}$ of $\mathrm{CH}_{2} \mathrm{Cl}_{2}, 2 \mathrm{mmol}$ ) was added. The medium was kept stirred in ice bath for $30 \mathrm{~min}$. After evaporation at room temperature, the complex, $\mathrm{H}_{2} \mathrm{~L}_{1} / \mathrm{Fe}(\mathrm{II})$, obtained as brown precipitate, was collected by filtration, washed with cold ethanol and dried in vacuum. The $\mathrm{H}_{2} \mathrm{~L}_{1} / \mathrm{Fe}$ (II) complex was obtained in $80 \%$ yield and in high purity $\left(\right.$ M.P. $=217^{\circ} \mathrm{C}$ ).

\section{Synthesis of complex of $\mathrm{H}_{2} \mathrm{~L}_{1} / \mathrm{Ni}(\mathrm{II})$}

The complex was prepared by the procedure described in the literature ${ }^{14}$. To a solution of $\mathrm{NiCl}_{2}(130 \mathrm{mg}$ in $20 \mathrm{~mL}$ of $n-\mathrm{BuOH}, 1 \mathrm{mmol})$, a solution of $\mathrm{H}_{2} \mathrm{~L}_{1}(540 \mathrm{mg}$ in $20 \mathrm{~mL}$ of $\mathrm{CH}_{2} \mathrm{Cl}_{2}, 2 \mathrm{mmol}$ ) was added. The mixture was stirred and refluxed for 1 hour. After evaporation in heat bath at $60{ }^{\circ} \mathrm{C}$, the product obtained, as oil solution, was dissolved in $4 \mathrm{~mL}$ of acetone. After evaporation of acetone, a precipitate was obtained, washed with cold $\mathrm{CH}_{2} \mathrm{Cl}_{2}$. By crystallization with diethyl ether, a white precipitate, $\mathrm{H}_{2} \mathrm{~L}_{1} / \mathrm{Ni}(\mathrm{II})$, was collected. The $\mathrm{H}_{2} \mathrm{~L}_{1} / \mathrm{Ni}$ (II) complex was obtained in $70 \%$ yield and in high purity (M.P. = $\left.223{ }^{\circ} \mathrm{C}\right)$.

\section{Synthesis of complex of $\mathrm{H}_{2} \mathrm{~L}_{1} / \mathrm{Zn}(\mathrm{II})$}

The synthesis of the complex is performed according to the method described in the litterature ${ }^{14,15}$. To a solution of $\mathrm{ZnCl}_{2}(136 \mathrm{mg}$ in $10 \mathrm{~mL}$ of $\mathrm{MeOH}, 1 \mathrm{mmol})$ a solution of $\mathrm{H}_{2} \mathrm{~L}_{1}\left(540 \mathrm{mg}\right.$ in $20 \mathrm{~mL}$ of $\mathrm{CH}_{2} \mathrm{Cl}_{2}, 2 \mathrm{mmol}$ ) was added. The mixture was stirred and refluxed for few minutes. After crystallization by slow evaporation of the solvent, the white precipitate obtained was washed with cold water. The $\mathrm{H}_{2} \mathrm{~L}_{1} / \mathrm{Zn}$ (II) complex was obtained in $73 \%$ yield and in high purity (M.P. $=192{ }^{\circ} \mathrm{C}$ ).

\section{Synthesis of complex of $\mathrm{H}_{2} \mathrm{~L}_{1} / \mathrm{Hg}(\mathrm{II})$}

According to the method described in the literature ${ }^{15}$, a solution of $\mathrm{H}_{2} \mathrm{~L}_{1}(540 \mathrm{mg}$ in $20 \mathrm{~mL}$ of $\left.\mathrm{CH}_{2} \mathrm{Cl}_{2}, 2 \mathrm{mmol}\right)$ was added to a solution of $\mathrm{HgCl}_{2}(136 \mathrm{mg}$ in $15 \mathrm{~mL}$ of $\mathrm{MeOH}$, $0.5 \mathrm{mmol}$ ). The mixture was stirred and refluxed for a few minutes. After crystallization, by slow evaporation of the solvent, the white precipitate obtained was washed with cold ethanol and dried in vacuum. The $\mathrm{H}_{2} \mathrm{~L}_{1} / \mathrm{Hg}$ (II) complex was obtained in $33 \%$ yield and in high purity (M.P. $\left.=220^{\circ} \mathrm{C}\right)$.

\section{Synthesis of complex of $\mathrm{H}_{2} \mathrm{~L}_{1} / \mathrm{Cu}(\mathrm{II})$}

According to the method described in the literature ${ }^{16}$, to form this complex, a solution of $\mathrm{H}_{2} \mathrm{~L}_{1}$ (540 mg in $20 \mathrm{~mL}$ of $\mathrm{CH}_{2} \mathrm{Cl}_{2}, 2 \mathrm{mmol}$ ) was added to a hot solution of $\mathrm{CuCl}_{2} \cdot 2 \mathrm{H}_{2} \mathrm{O}$ (170.5 mg in $15 \mathrm{~mL}$ of EtOH, $1 \mathrm{mmol}$ ). The mixture was stirred for 30 minutes. After crystallization by slow evaporation of the solvent, the blue precipitate obtained was washed with cold water, then with ethanol and later dried in vacuum. The $\mathrm{H}_{2} \mathrm{~L}_{1} / \mathrm{Cu}$ (II) complex was obtained in $71 \%$ yield and in high purity (M.P. $=228^{\circ} \mathrm{C}$ ). 


\section{Preparation of metal complexes of $\mathrm{N}$-(2-methylphenyl), $N^{\prime}-(2-c h l o r o p h e n y l)$ thiourea $\left(\mathrm{H}_{2} \mathrm{~L}_{2}\right)$}

$\mathrm{Fe}(\mathrm{II}), \mathrm{Ni}(\mathrm{II}), \mathrm{Zn}(\mathrm{II}), \mathrm{Hg}(\mathrm{II})$ and $\mathrm{Cu}(\mathrm{II})$ complexes of $\mathrm{H}_{2} \mathrm{~L}_{2}$ were prepared following the same procedures described for the complexes of $\mathrm{H}_{2} \mathrm{~L}_{1}$, but carrying out minor appropriate modifications as described below:

Synthesis of complex of $\mathrm{H}_{2} \mathrm{~L}_{2} / \mathrm{Fe}(\mathrm{II})$

The complex was prepared by the procedure described with $\mathrm{H}_{2} \mathrm{~L}_{1}$ by using $553 \mathrm{mg}$ ( $2 \mathrm{mmol}$ ) of $\mathrm{H}_{2} \mathrm{~L}_{2}$. The dried complex was grey in color; it was obtained in $66 \%$ yield and in high purity (M.P. $\left.=218^{\circ} \mathrm{C}\right)$.

\section{Synthesis of complex of $\mathrm{H}_{2} \mathrm{~L}_{2} / \mathrm{Ni}(\mathrm{II})$}

The reaction is performed as described above with $\mathrm{H}_{2} \mathrm{~L}_{1}$ by using $130 \mathrm{mg}$ of $\mathrm{NiCl}_{2}(1 \mathrm{mmol})$. A yellow orange complex of $\mathrm{H}_{2} \mathrm{~L}_{2} / \mathrm{Ni}$ (II) was obtained in $62 \%$ yield and in high purity (M.P. $=212^{\circ} \mathrm{C}$ ).

\section{Synthesis of complex of $\mathrm{H}_{2} \mathrm{~L}_{2} / \mathrm{Zn}(\mathrm{II})$}

The complex was prepared by the following the same procedure described for the synthesis of $\mathrm{H}_{2} \mathrm{~L}_{1} / \mathrm{Zn}$ (II) by using $553 \mathrm{mg}$ of $\mathrm{H}_{2} \mathrm{~L}_{2}(2 \mathrm{mmol})$ instead of $540 \mathrm{mg}$ of $\mathrm{H}_{2} \mathrm{~L}_{1}$. A white precipitate complex of $\mathrm{H}_{2} \mathrm{~L}_{2} / \mathrm{Zn}$ (II) was obtained in $66 \%$ yield and in high purity (M.P. $=195{ }^{\circ} \mathrm{C}$ ).

\section{Synthesis of complex of $\mathrm{H}_{2} \mathrm{~L}_{2} / \mathrm{Hg}(\mathrm{II})$}

The same procedure described for the preparation of the complex $\mathrm{H}_{2} \mathrm{~L}_{1} / \mathrm{Hg}$ (II) was implemented for preparing the complex $\mathrm{H}_{2} \mathrm{~L}_{2} / \mathrm{Hg}$ (II) by using $553 \mathrm{mg}$ of $\mathrm{H}_{2} \mathrm{~L}_{2}(2 \mathrm{mmol})$ instead of $540 \mathrm{mg}$ of $\mathrm{H}_{2} \mathrm{~L}_{1}$. A white precipitate complex of $\mathrm{H}_{2} \mathrm{~L}_{2} / \mathrm{Hg}$ (II) was obtained in $29 \%$ yield and in high purity (M.P. $\left.=225^{\circ} \mathrm{C}\right)$.

\section{Synthesis of complex of $\mathrm{H}_{2} \mathrm{~L}_{2} / \mathrm{Cu}(\mathrm{II})$}

The complex was prepared by the procedure described for the synthesis of $\mathrm{H}_{2} \mathrm{~L}_{1} / \mathrm{Cu}$ (II) whereby $553 \mathrm{mg}$ of $\mathrm{H}_{2} \mathrm{~L}_{2}(2 \mathrm{mmol})$ was used in place of $540 \mathrm{mg}$ of $\mathrm{H}_{2} \mathrm{~L}_{1}$. The blue precipitate of $\mathrm{H}_{2} \mathrm{~L}_{2} / \mathrm{Cu}(\mathrm{II})$ complex was obtained in $55 \%$ yield and in high purity $\left(\mathrm{M} . \mathrm{P} .=210{ }^{\circ} \mathrm{C}\right.$.)

\section{Results and Discussion}

The major infrared bands of Ligands $\mathrm{H}_{2} \mathrm{~L}_{1}$ and $\mathrm{H}_{2} \mathrm{~L}_{2}$ and their complexes are presented in Tables 1 and 2 respectively. The IR spectra of the complexes show a large number of bands which occur at various intensities in IR spectra due to the polarity of the double bond and the electron donating groups at the ortho-position of the substituent on the $\operatorname{aromatic}^{17}$. Of these, the focus is on the characteristic infrared bands, needed to verify the complexation objective of this study, that are assigned to the bonds between the metals and the ligands.

Thiourea is potentially capable of forming coordination bonds by both sulfur and nitrogen, even if the basicity of the ligand is extremely low ${ }^{18}$. The shift of the $v(\mathrm{~N}-\mathrm{H})$ band from $3333 \mathrm{~cm}^{-1}$ ) before complexation towards a higher frequency regions (up to $3364 \mathrm{~cm}^{-1}$ in Table 1 and $3443 \mathrm{~cm}^{-1}$ in Table 2) after complexation, in addition to the constant decrease of $v(C=S)+v(C-N)$ vibrations from $766 \mathrm{~cm}^{-1}$ before complexation to $753 \mathrm{~cm}^{-1}$ in Table 1 and even $753 \mathrm{~cm}^{-1}$ in Table 2 are indicatives of metal to ligand $\pi$-electron interactions ${ }^{19-21}$, and that the coordination occurs through the $\mathrm{S}$ atom of the $\mathrm{C}=\mathrm{S}$ group ${ }^{22,23}$. These result are obtained for $\mathrm{Fe}(\mathrm{II}), \mathrm{Ni}(\mathrm{II}), \mathrm{Zn}(\mathrm{II})$ and $\mathrm{Cu}(\mathrm{II})$. 
Unlike the above metals, the L-Hg complexation shows a different IR behavior. The absorption band $v(\mathrm{~N}-\mathrm{H})$ at $3333 \mathrm{~cm}^{-1}$ for the free ligand is significant reduced to reach $3290 \mathrm{~cm}^{-1}$ in Table 1 and $3299 \mathrm{~cm}^{-1}$ in Table 2, as well, the absorption bands $v(\mathrm{C}=\mathrm{S})+v(\mathrm{C}-\mathrm{N})$ was observed to undergo minor reduction indicating that the $\mathrm{Hg}$ (II) binds by the nitrogen atom ${ }^{24,25}$.

Table 1. Infrared data of the ligand $\mathrm{H}_{2} \mathrm{~L}_{1}$ and its complexes, FT-IR $(\mathrm{KBr}) \mathrm{cm}^{-1}$

\begin{tabular}{ccccccc}
\hline $\mathrm{H}_{2} \mathrm{~L}_{1}$ & $\mathrm{H}_{2} \mathrm{~L}_{1} /$ & $\mathrm{H}_{2} \mathrm{~L}_{1} /$ & $\mathrm{H}_{2} \mathrm{~L}_{1} /$ & $\mathrm{H}_{2} \mathrm{~L}_{1} /$ & $\mathrm{H}_{2} \mathrm{~L}_{1} /$ & Assignements \\
\hline $3333 \mathrm{~S}$ & 3344 & 3334 & 3344 & 3290 & 3364 & $v(\mathrm{~N}-\mathrm{H})$ \\
3136 & 3119 & 3136 & 3119 & 3022 & 3139 & $v(\mathrm{Ar}-\mathrm{H})$ \\
$2946 \mathrm{~m}$ & 2941 & 2946 & 2941 & 2923 & 2958 & $v(\mathrm{C}-\mathrm{H})$ \\
1629 & 1627 & & & 1639 & 1647 & $v(\mathrm{C}=\mathrm{C})$ \\
$1532 \mathrm{w}$ & 1531 & 1531 & & 1564 & 1537 & $v(\mathrm{C}-\mathrm{N})+\delta(\mathrm{N}-\mathrm{H})$ \\
$1487 \mathrm{~S}$ & 1494 & 1488 & 1494 & 1457 & 1492 & $v(\mathrm{~N}-\mathrm{C}-\mathrm{N})+v(\mathrm{C}=\mathrm{S})$ \\
1342 & & & & 1377 & & $v(\mathrm{C}=\mathrm{S})+\delta(\mathrm{N}-\mathrm{C}-\mathrm{S})$ \\
$1274 \mathrm{~S}$ & 1342 & 1273 & 1259 & 1291 & 1278 & $v(\mathrm{C}=\mathrm{S})+\delta(\mathrm{N}-\mathrm{C}-\mathrm{N})$ \\
1026 & & & 1052 & & & $v(\mathrm{~N}-\mathrm{C}-\mathrm{N})+v(\mathrm{C}=\mathrm{S})$ \\
$766 \mathrm{w}$ & 763 & & 753 & 764 & 763 & $v(\mathrm{C}=\mathrm{S})+v(\mathrm{C}-\mathrm{N})$ \\
717 & & 716 & & & & $v(\mathrm{C}=\mathrm{S})+v(\mathrm{C}-\mathrm{N})$ \\
\hline
\end{tabular}

Only characteristic peaks are labeled as: S: Strong; m: middle; $w$ : weak

Table 2. Infrared data of the ligand $\mathrm{H}_{2} \mathrm{~L}_{2}$ and its complexes, FT-IR $(\mathrm{KBr}) \mathrm{cm}^{-1}$

\begin{tabular}{ccccccc}
\hline $\mathrm{H}_{2} \mathrm{~L}_{2}$ & $\mathrm{H}_{2} \mathrm{~L}_{2} /$ & $\mathrm{H}_{2} \mathrm{~L}_{2} /$ & $\mathrm{H}_{2} \mathrm{~L}_{2} /$ & $\mathrm{H}_{2} \mathrm{~L}_{2} /$ & $\mathrm{H}_{2} \mathrm{~L}_{2} /$ & \multirow{2}{*}{ Assignements } \\
\hline $3333 \mathrm{~S}$ & 3344 & 3334 & 3343 & 3299 & 3443 & $v(\mathrm{~N}-\mathrm{H})$ \\
3135 & 3136 & 3118 & 3115 & 3160 & 3131 & $v(\mathrm{Ar}-\mathrm{H})$ \\
$2946 \mathrm{~m}$ & 2951 & 2941 & 2941 & 2965 & 2946 & $v(\mathrm{C}-\mathrm{H})$ \\
1633 & 1632 & 1628 & & 1640 & 1629 & $v(\mathrm{C}=\mathrm{C}) \mathrm{Ar}$ \\
$1532 \mathrm{~W}$ & 1533 & 1583 & 1531 & 1540 & 1552 & $v(\mathrm{C}-\mathrm{N})+\delta(\mathrm{N}-\mathrm{H})$ \\
$1487 \mathrm{~S}$ & 1492 & 1491 & 1490 & 1504 & 1474 & $v(\mathrm{~N}-\mathrm{C}-\mathrm{N})+v(\mathrm{C}=\mathrm{S})$ \\
1380 & & & 1435 & & & $v(\mathrm{C}=\mathrm{S})+\delta(\mathrm{N}-\mathrm{C}-\mathrm{S})$ \\
$1274 \mathrm{~S}$ & 1290 & & & 1289 & 1292 & $v(\mathrm{C}=\mathrm{S})+\delta(\mathrm{N}-\mathrm{C}-\mathrm{S})$ \\
$766 \mathrm{w}$ & 718 & & 753 & 765 & 752 & $v(\mathrm{C}=\mathrm{S})+v(\mathrm{C}-\mathrm{N})$ \\
\hline
\end{tabular}

The above results lead us to propose structures as shown in Scheme $3(n=2)$.

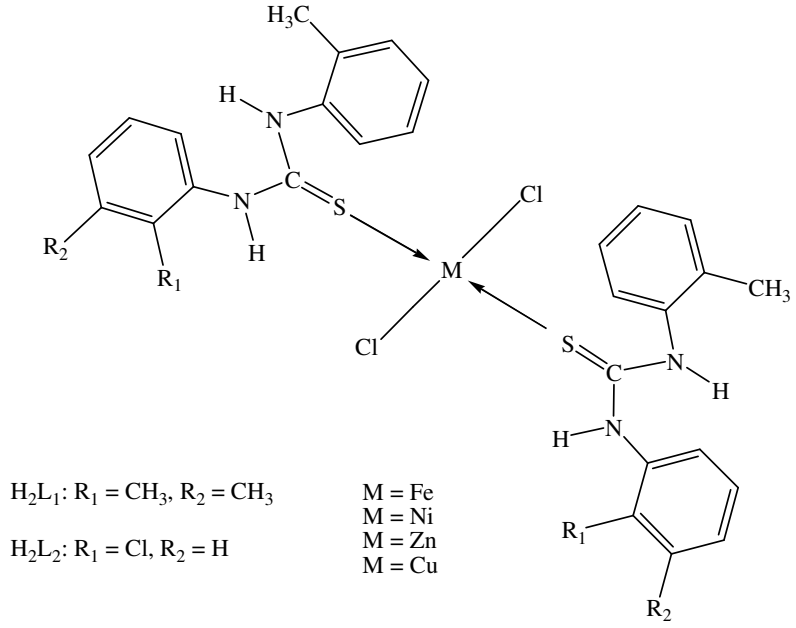




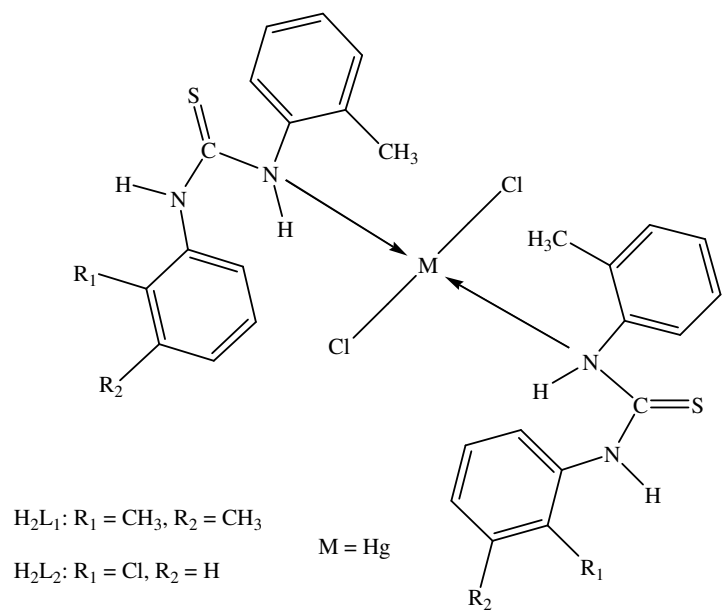

Scheme 3. A possible mechanism for the complexes ligand/M(II) with $n=2$

\section{Conclusion}

Thiourea derivatives have caught attention both at the theoretical and the practical levels. Thiourea and its derivatives have found application in biological activities, in trapping transition and heavy metals and have demonstrated its potential in both fields of coordination chemistry and environmental sustainability. In this regard, the synthesis of thiourea derivatives has become, in itself, an aim and the application of such new derivatives has become a perspective potential to look forward to. Accordingly, this study has fulfilled its objective through the synthesis and the characterization of five complexes with two thiourea derivatives: $N$-(2-methylphenyl), $N^{\prime}$-(2,3-dimethylphenyl) thiourea $\left(\mathrm{H}_{2} \mathrm{~L}_{1}\right)$ and $N$-(2-methylphenyl), $N^{\prime}$-(2chlorophenyl) thiourea $\left(\mathrm{H}_{2} \mathrm{~L}_{2}\right)$. These compounds possess two aryl-bisubstutated thioamide groups, which can react as potential monodentate ligands forming stable complexes, insoluble or poorly soluble in water, with transition metals: $\mathrm{Fe}(\mathrm{II}), \mathrm{Zn}(\mathrm{II}), \mathrm{Ni}(\mathrm{II}), \mathrm{Hg}(\mathrm{II})$ and $\mathrm{Cu}(\mathrm{II})$.

The application part of the objective still needs to be addressed through carrying out comparative studies of the biological activity and the therapeutic properties of the free thiourea derivatives and their complexes with the above metals to confirm the importance of these two derivatives.

IR spectroscopy continues to present itself as a powerful and a reliable characterization technique. The interpretation of the obtained IR results has been verified by comparison with similar studies reported in the literature. The results obtained verified the complexion capacity of the ligands towards transition metals.

The heteroatoms $\mathrm{N}$ and $\mathrm{S}$ present different coordination types M-N or M-S. In the case of $\mathrm{Fe}(\mathrm{II}), \mathrm{Zn}(\mathrm{II}), \mathrm{Ni}(\mathrm{II})$ and $\mathrm{Cu}(\mathrm{II})$, the coordination is found to be done by the sulfur atom $\mathrm{S}$. For $\mathrm{Hg}(\mathrm{II})$, the coordination is carried out by the nitrogen atom $(\mathrm{N})$. This shows that the coordination nature depends on the electronic structure, the steric effect of the ligands and the nature of the metal cation. The results of this work confirm the two possible modes of coordination $\mathrm{N}$ and $\mathrm{S}$.

\section{References}

1. (a) Robson R, J Chem Soc., Dalton Trans., 2000, 3735-3744; DOI:10.1039/B003591M (b) Atrees M S, Metwally E, Demerdash M and Salem H, 
J Rad Res Appl Sci., 2016, 9(3), 207-216; DOI:10.1016/j.jrras.2015.02.004 (c) Alodan M and Smyrl W, Electrochim Acta, 1998, 44(2-3), 299-309; DOI:10.1016/S00134686(98)00060-7

2. Dalko P I and Moisan L, Angew Chem., Int., 2004, 43(39), 5138-5175;

DOI:10.1002/anie.200400650

3. Fuerst D E and Jacobsen E N, J Am Chem Soc., 2005, 127(25), 8964-8965; DOI:10.1021/ja052511x

4. (a) Hoashi Y, Yabuta T, Yuan P, Miyabe H and Takemoto Y, Tetrahedron, 2006, 62(2-3), 365-374; DOI:10.1016/j.tet.2005.08.109 (b) Hoashi $\mathrm{Y}$, Okino $\mathrm{T}$ and Takemoto Y, Angew Chem., Int Ed., 2005, 44(26), 4032-4035; DOI:10.1002/anie.200500459 (c) Okino T, Hoashi Y, Furukawa T, Xuenong X and Takemoto Y J, Am Chem Soc., 2005, 127(1), 119-125; DOI:10.1021/ja044370p

5. (a) Wang J, Li H, Yu X, Zu L and Wang W, Org Lett., 2005, 7(19), 4293-4296; DOI:10.1021/ol051822+ (b) Sohtome Y, Tanatani A, Hashimoto Y and Nagasawa K, Tetrahedron Lett., 2004, 45(43), 5589-5592; DOI:10.1016/j.tetlet.2011.08.051

6. Joly G D, Jacobsen E N J, Am Chem Soc., 2004, 126(13), 4102-4103; DOI:10.1021/ja0494398

7. Henderson W, Kemmitt R D W, Mason S, Moore M R, Fawcett J and Russell D R, $J$ Chem Soc., Dalton Trans., 1992, 1, 59-66; DOI:10.1039/DT9920000059

8. Eweis M, Elkholy S S and Elsabee M Z, J Biol Macromol., 2006, 38(1), 1-8; DOI:10.1016/j.ijbiomac.2005.12.009

9. Ugur D, Florke U, Kulcu N and Arslan H, Acta Cryst E., 2003, 59, 1345-1346.

10. Steele M R, Monti C, Gennari C, Piarulli U, Andreoli F, Vanthuyne N and Roussel C, Tetrahedron: Asymmetry, 2006, 17(6), 999-1006; DOI:10.1016/j.tetasy.2006.03.008

11. Li Z, Liu Z, Liao Q X L, Wei Z B, Long L S and Jiang Y B, Com Ren Chimie, 2008, 11(1-2), 67-72; DOI:10.1016/j.crci.2007.06.009

12. Bellec N, Lorcy D and Robert A, Synthesis, 1998, 10, 1442-1446; DOI:10.1055/s1998-2183

13. Lobana T S, S'anchez A, Casas J S, J Chem Soc, Dalton Trans., 1997, 22, 4289-4300; DOI:10.1039/A703726K

14. El-Bahy G M S, El-Sayed B A and Shabana A A, Vibrational Spectroscopy, 2003, 31(1), 101-107; DOI:10.1016/S0924-2031(02)00099-1

15. Gosavi R K and Rao C N R, J Inorg Nucl Chem., 1967, 29(8), 1937-1945; DOI:10.1016/0022-1902(67)80453-6

16. Jensen K A and Nielsen P H, Acta Chem Scand., 1966, 20, 597-629; DOI:10.3891/acta.chem.scand.20-0597

17. Yahyazadeh A and Ghasemi Z, Eur Chem Bull., 2013, 2(8), 573-575; DOI:10.17628/ECB.2013.2.573

18. Stewart J E, J Chem Phys., 1957, 26, 248-254.

19. Kashyap B C, Taneja A D and Banerji S M, J Inorg Nucl Chem., 1975, 37(2), 612-615; DOI:10.1016/0022-1902(75)80397-6

20. Kashyap B C, Taneja A D and Banerji S M, J Inorg Nucl Chem., 1975, 37(6), 15421544; DOI:10.1016/0022-1902(75)80813-X

21. Tucker I, Singh R P and Zacharias P S, Indian J Chem., 1979, 18A, 60-61.

22. Satpathy K C, Mishra H P and Patel B N, Indian J Chem., 1992, 22A, 338.

23. Andrea S, Tscheatschal F, Dietze F and Philip T, J Prakt Chem., 1991, 333, 501.

24. Mishra L and Pandey A K, Polyhedron, 1992, 11, 4243-4251.

25. Chavan M C, Deshpande V D and Vaida P V, Asian J Chem., 1992, 4(2), 246-250. 